\title{
Corporate social responsibility impact on talent retention among Generation Y
}

Talent retention among Generation Y

\author{
Intan Azurin Zainee and Fadilah Puteh \\ Faculty of Administrative Science and Policy Studies, Universiti Teknologi MARA, \\ Shah Alam, Malaysia
}

\begin{abstract}
Purpose - As the new emerging workforce, Generation Y (Gen Y) is said to be demanding, influential and possessing strong bargaining power. This study examines the impact of corporate social responsibility (CSR) on employee retention among Gen Y in the accounting profession. CSR is widely researched subject due to its applicability in multidisciplinary fields and industries. This research intends to investigate the nexus between CSR and human capital disciplines. It employs Carroll's pyramid of CSR as the main theoretical framework to establish its relationship with talent retention among Gen Y employees. This study has a threefold aim: (1) to determine the level of CSR awareness, (2) to determine the relationship between CSR dimensions and talent retention and (3) to examine the effect of CSR dimensions on talent retention.

Design/methodology/approach - The paper opted for an exploratory study using the structured questionnaire. A total of 377 Gen Y accountants who are currently working in accounting firms located in Klang Valley, Malaysia, were involved as respondents. Data were analyzed using descriptive, correlation and regression analyses to answer the research objectives.

Findings - The paper provided empirical insights about the impact brought by CSR practices in financialbased firms on employee retention. It was found that all CSR elements, as suggested by Carroll, have a significant relationship with employees' retention. The interaction between the CSR elements and employee retention accounts for $16 \%$ of the research model. Based on the multiple regression analysis, it was found that only two CSR elements are the significant predictors of employee retention among Gen $\mathrm{Y}$ in the case of financial-based firms in Malaysia.

Research limitations/implications - This research covers Gen Y employees in accounting firms; thus, generalization is not applicable to other generations. Besides, the predictors of the research study utilize Carroll's pyramid of CSR. Therefore, future research studies are encouraged to validate the research model into other sectors. Other models of CSR could also be used.

Practical implications - This paper includes implication for the organization to understand employee retention practices on Gen Y who are currently dominating the workforce.

Originality/value - This paper fulfills an identified need to study how CSR practices could enhance employee retention among Gen $\mathrm{Y}$ in the organization.
\end{abstract}

Keywords Corporate social responsibility, Gen Y, Employee retention

Paper type Research paper

\section{Introduction}

This article presents the impact of corporate social responsibility (CSR) on employee retention in Generation Y (Gen Y) in a financial services industry, particularly in the accounting profession. Thus, the discussions in the next sections revolve around CSR, employee retention and Gen Y. Globalization has pushed many corporations to integrate globally; hence, employees who serve as key intangible assets to the corporations should aid as a

(C) Intan Azurin Zainee and Fadilah Puteh. Published in Revista de Gestão. Published by Emerald Publishing Limited. This article is published under the Creative Commons Attribution (CC BY 4.0) license. Anyone may reproduce, distribute, translate and create derivative works of this article (for both commercial and non-commercial purposes), subject to full attribution to the original publication and authors. The full terms of this license may be seen at http://creativecommons.org/licences/by/4.0/ legalcode 
REGE 27,4 powerful source of competitive advantage. However, the ability to retain valuable employees has become one of the challenging issues faced by many organizations today. These valuable employees have become valuable resources for the companies so that they can provide and serve as the competitive advantage for the organizations' survival (Bhattacharya, Sen, \& Korschun, 2008, Heinrich, 2017). Heinrich (2017) also mentioned that in today's competitive working environment, business organizations are facing a "hard time" in retaining key valuable employees; this problem has caught the attention of not only the top organizational managements but also scholars in the field of human resources. Mushtaq (2013) in her study found that corporations today are constantly striving to cope with the competitive market, which in turn has made retaining valuable employees even more challenging. In addition, Tatoglu, Glaister, and Demirbag (2016) concurred with Mushtaq's (2013) finding, stressing that retaining talent has emerged as an overwhelming issue faced by corporations due to increasing turnover costs including the loss of corporate memory, productivity and intellectual and social capitals. Despite the gravity of such, evidence from the Malaysia Productivity Corporation revealed that only a few organizations focus on retaining their talented employees (Tajuddin, Ali, \& Kamaruddin, 2015).

In 2015, a survey by Michael Page, the world's leading professional recruitment consultancy involving 869 working Malaysian professionals, found that employee retention remains to be a significant challenge to Malaysian employers (Michael Page Malaysia, 2015a, b). The report further added that retention would be a key concern for Malaysian employers as $44 \%$ of professionals were expected to leave their current role in the next 12 months, while $40 \%$ stated that they only saw themselves in the same role for the next one to three years (Cooper, 2015). Moreover, both the "2014 Global Workforce Study," involving 32,000 employees globally, and the "Talent Management and Rewards Study," carried out by Towers Watson in 2014 involving more than 1,600 organizations worldwide, found that Malaysia appeared to be struggling to address the war of talent and employee retention continued to be a key challenge for Malaysian employers across different industries. The retention scores have also declined steadily, despite an increase of 40\% since 2012 as a result of low employee engagement. Surprisingly, highly engaged employees tend to leave organizations within two years of working with the current organization, resulting in an increase of engagement percentage from 30\% since 2012 to $31 \%$ in 2014 . More and more employees, who accounted for $36 \%$ of the surveyed employees, indicated that they were likely to leave the organizations compared to $29 \%$ in 2012 (Yin, 2015).

CSR is widely researched due to its applicability in multidisciplinary fields, such as business and management, finance and engineering (Bouvain, Baumann, \& Lundmark, 2013; Cooke \& He, 2010; Pienaar, 2010; Shanmugam, 2013) and industries, such as financial services, oil and gas and manufacturing (Aguilera, Rupp, Williams, \& Ganapathi, 2007, Ferreira \& Real de Oliveira, 2014; Heinrich, 2017). As a matter of fact, CSR is one of the important tools for business organizations to achieve competitive advantage (Pienaar, 2010). It happens due to the increasing pressure from the public for business organizations to adopt and practice ethical and philanthropic responsibilities along with economic objectives and legal duties. In consequence, the social responsibility awareness has increased from year to year along with government's regulations imposed on companies, especially publicly listed companies, to practice CSR and to oblige them to disclose their CSR activities in their annual reports. According to Noor Emilina, Nurul Akmal, Nur Raihana, Nur Syuhada, and Nurul Fatma (2015), considering the pressure from public and nongovernmental organizations (NGOs), the Malaysian Government has taken serious steps to embed the CSR idea into every corporation, especially publicly listed companies in Malaysia. The CSR concept is seen as an extensive plan of strategic management by many corporate leaders, which helps companies sustain their businesses (Pyszka \& Gajda, 2015). 
Several studies have identified Gen Y as a newly emerging talents wave in the labor market. Being the new cohort of the labor force, Gen Y poses distinct characteristics than the previous cohorts of Generation X (Gen X) and baby boomers (Fadilah, Maniam, \& Nafis, 2015). As opposed to previous generations, these studies have found that, in general, Gen $Y$ individuals are very demanding, possessing strong bargaining power and very influential workforce. A study by Fadilah, Maniam, and Nafis (2015) found that Gen Y is disloyal toward its organizations, which in turn contributes to a high turnover rate. Thus, organizations are at a conundrum in developing the best strategies to retain them. With this in mind, the application of CSR practices in the organization could be seen as a significant factor in improving employee retention.

Although Holland, Sheehan, Donohue, and Pyman (2007) had suggested that every corporation should align their employee retention strategies with CSR to keep top performers in the company and to ensure their company's long-term sustainability, research between the two fields is confined only to a few industries. Besides, much research studies on CSR mainly focus on the macro level exploration (Aguinis \& Glavas, 2012) and institutional level, where only a little emphasis is given to internal stakeholders (Aguinis \& Glavas, 2013). Lately, the focus has diverted to studies on the internal stakeholders of companies, namely, the human capital, which serves as the organization's most valuable key asset. Accordingly, employees have become the central attention of CSR as well as human resource research, where issues concerning employee retention, especially the top performers, become crucial (Foong, Joy, Lim, Phang, \& Tiong, 2015). CSR and its relationship with employee retention make up the focus of this study since many research studies which investigated the connections between these two factors appear to be limited and inadequately available.

This study pays a specific focus on the financial services industry. There are a few studies involving Gen $\mathrm{Y}$ and employee retention in various disciplines and contexts. Among them, one can find studies on the retention of Gen Y employees in Malaysia's small and mediumsized enterprises (Wee, 2013), employee retention in the manufacturing industry in six Asian countries (Zheng, Soosay, \& Hyland, 2007), employee retention in the manufacturing industry in Malaysia (Foong, Joy, Lim, Phang, \& Tiong, 2015), employee retention in the logistics industry in the Columbus region (Cofer, 2010), employee retention and its factors in the textile industry in Yazd Province, Iran (Shahvazian, Mortazav, Lagzian, \& Rahimnia, 2016), and employee retention strategy in the health-care industry (Gering \& Conner, 2002). However, studies on the financial services industry are scarce, particularly considering the accounting sector in Malaysia. In Malaysia, many accountants are mostly concentrated in the Klang Valley areas, which cover the state of Selangor and the Federal Territory of Kuala Lumpur. Based on the list of registered members in the Malaysian Institute of Accountants (MIA) in 2017, most Gen Y accountants are based in Selangor (12,941) and Kuala Lumpur $(7,253)$. In 2017, according to the Emerald Insight database, less than 400 academic articles about employee retention in the Malaysian settings have been published and yet there are only a few studies on the financial services industry.

Andrew Robb of Deloitte UK discovered that job positions in accountancy were of the top ten hardest job positions to fill across the globe (Boersma, 2014). Evidence in a report by TalentCorp (2016) indicated six sectors that are suffering from skills imbalance, including the accounting sector. Hence, this supports the claim that the accounting sector is among the critical sectors in Malaysia that needs attention in order to solve the problem of employee retention. Obviously, corporations need to realize the importance of employee retention so that they can withstand the impact of talent shortages. A study on accounting students in Malaysia by Nasir, Ghani, and Said (2009) identified several major reasons that may lead to the shortage of accountants in Malaysia, including difficulties in filling the membership form, high membership fees, no added benefits for current employment and the lack of ambition to become an accountant. Although audit and tax are the main services provided, the growth of 
REGE 27,4

this sector has led the industry to provide non-related accountancy services and consultations as well. In addition, due to the growth and demand of this sector, the accounting profession also has various levels of expertise and seniority. Most major employers, such as the Big-4 accounting firms, global corporations and major listed companies focus more on retaining their employees to fulfill the various functions in their organizations.

Thus, this paper intends to accomplish the following objectives: (1) to determine the level of CSR awareness, (2) to determine the relationship between Carroll's (1991) CSR dimensions (economic, legal, ethical and philanthropic responsibilities) and employee retention and (3) to examine the effect of Carroll's (1991) CSR dimensions on the retention of Gen Y employees. The focus of the study is on the financial services industry, specifically the accounting sector in Klang Valley. Several key concepts, namely employee retention, CSR and Gen Y, are also presented in this article.

\section{Literature review and hypotheses development}

The following subsections discuss the important concepts and variables of the study, namely, employee retention, CSR and Gen Y. The concepts are explained to give a clear understanding as supported by past studies that link the variables of the study, followed by the hypotheses development derived from the review of literature.

\subsection{Employee retention}

Employee retention is one of the most discussed topics in the human resources field with a high variety of journals and articles found in search engines and journal databases (Hayfaa et al., 2017). Hayfaa et al. (2017) further argued that many organizations are struggling to keep their talents and having difficulties in seeking the best strategies in developing those talents. A talent, as observed by Wee (2013), is an individual who has the specific skills, knowledge, capability and experience to fulfill the current and oncoming demands of companies. Ibrahim and Zayed (2018), Karunathilaka, AbYajid, and Khatibi (2016) and Weerasinghe (2017) echoed the important and significant role of employee retention as part of talent management activities. Karunathilaka, Ab Yajid, and Khatibi (2016) indicated that employee retention is a measure to keep the talent contributing to the success of the organization. Ibrahim and Zayed (2018) concurred with the affirmation that the effort to retain talent involves all activities that prevent talented employees from leaving the organization. Weerasinghe (2017) emphasized that organizations must invest on talent in order to retain high-performing employees, acquiring competitive advantage. Employee retention facilitates organizations in maintaining competitive advantage, which in turn helps them mitigate the direct cost of losing talents and the loss of tacit knowledge (Hayfaa et al., 2017).

With the growing economic development, combined with the impact of globalization, Malaysia has experienced rapid expansion of different industries across the nation. This is reflected through increases in the demand for professionals, especially in the accounting sector in which there is a need for the training of more professional accountants and financial experts to help companies sustain in the competitive environment. Nonetheless, many firms are facing pressure exacerbated by the issues of employee turnover and reduced interest among fresh graduates to pursue a career as accountants, despite the lucrative salary (Nasir, Ghani, \& Said, 2009). Due to the high turnover rates, employee retention has become a major concern for accounting firms worldwide (Chin, Lau, Leong, Lim, \& Yip, 2013). Chin, Lau, Leong, Lim, and Yip (2013) further asserted that accounting firms incur relevant costs as a result of employees leaving their organizations. Only a few studies have been conducted on accounting professionals in Malaysia (Gomes, 2017). Therefore, the expansion of the nation's 
economic landscape has made this study even more relevant since a small number of accountants could possibly make accounting firms struggle to retain their top talents and skillful employees. The unstable economic condition in recent years has made employee retention an increasingly important factor in determining which companies would thrive and which would maintain sufficient talent levels (Schmidt, 2016). The war for talents has made the competition among organizations even more intense. As a result, many strategies have been employed by organizations to retain their employees. The concept of engagement, job satisfaction, the role of effective leaders and careful selection of human resources' (HR) best practices are among the strategies that have been widely discussed and adapted for the purpose of employee retention.

Several studies have examined the nexus between CSR and employee retention. CSR has been proven to have an impact on employees in terms of creative involvement (Aguinis \& Glavas, 2012), employees' relationships (Glavas, 2016) and employee retention (Bhattacharya, Sen, \& Korschun, 2008). To a certain extent, CSR helps improve the working environment in many aspects. Effective CSR helps enhance the sense of belonging in employees, improve skills and motivation, lead to better productivity, lower rate of attrition and ultimately leads to higher job satisfaction and increased retention rate (Jun \& Seng, 2016). Duff (2016) indicated that CSR and employee retention were connected, especially in accounting-related firms because people tend to see this type of employment as an old-fashioned career. Duff (2016) further argued that CSR makes the accounting profession more attractive to current employees. For instance, the existence of volunteering and how professional accounting firms tackle gender and inclusive issues make the firms more attractive to potential employees and prevent talented employees from leaving the organizations.

Although CSR is among the strategies used to gain competitive advantage, it can only be accomplished through its integration with all aspects of the organization's operations (Stephenson, 2009). CSR is not peculiar in today's organizations due to its effectiveness in enhancing and maintaining organizational reputation. Although it is proven as a helpful strategy, many corporations seem to ignore the importance of CSR in their operations. The fact is CSR is seen as a strong employer brand that is useful to help a company engage with its employees and is one of the best ways to retain talent. This is based on a global study which investigates the relationship between HR and CSR (Pyszka \& Gajda, 2015). Thus, as companies practice CSR, they become more aware of employee engagement and engaged employees perform more productively, thus helping to increase their tendency to stay within the organization in the long run (Meister, 2012).

\subsection{Corporate social responsibility (CSR)}

CSR is an activity that goes beyond the law and interest of a firm (McWilliam \& Siegel, 2001). In light of unethical accounting scandals such as that of Enron, WorldCom and Satyam, the accounting and finance sectors have evolved and changed their ways in order to ensure that accounting firms and other corporations across different sectors give due attention to disclosure practices (Claydon, 2011). Besides, the debate on company's obligations on issues that go beyond the legal standard has attracted scholars to pay closer attention to CSR.

Carroll (1991) had come out with a more comprehensive and accepted definition of CSR. Carroll (1999) termed CSR as "the social responsibility of business encompassing the economic, legal, ethical, and discretionary expectations that society has of organizations at a given point in time." Carroll (1991) developed a pyramid with four CSR dimensions, namely, economic, legal, ethical and philanthropic. Economic responsibilities as defined by Carroll (1991) entail the responsibilities of business entities in making profits through the production and selling of goods or services to the society. Meanwhile, legal responsibilities refer to "compliance with the laws and regulations established by federal, state, and local 
REGE 27,4

\section{4}

governments as the ground rules under which businesses must operate." Ethical responsibilities are defined as "activities and practices that are expected or prohibited by societal members even though they are not codified into law." Finally, philanthropic responsibilities are described as the "corporate actions that are in response to society's expectation that businesses be good corporate citizens which include actively engaging in acts or programs to promote human welfare or goodwill."

The CSR model developed by Carroll (1991) is widely used by many corporations to engage in CSR activities with their stakeholders. Business entities are expected to fully address all four CSR responsibilities to the society from the moment they commence operations (Dusuki \& Tengku Mohd Yusof, 2008). Ma, Qu, and Eliwa (2012) found that, despite numerous reconstructions of Carroll's (1991) CSR pyramid by numerous researchers, the original remains the best known model of CSR, employed in almost all written texts relating to CSR and is one of the most cited in CSR literature studies (Baden, 2016). Schwartz and Carroll (2003), as cited by Baden (2016), have listed numerous research and educational texts that represent Carroll's (1991) CSR pyramid and concluded that the model's frequent mention in CSR literature suggests that it remains a leading CSR paradigm of social issues in the management field. Hence, Carroll's (1991) CSR pyramid remains relevant in the modern context with respect to the understanding of the concept and application of CSR.

With respect to the nexus between the economic dimension and employee retention, corporations have the responsibility to increase their profits based on the argument that the sole purpose of a business is to safeguard the interests of shareholders. This viewpoint is absolutely inseparable from the primary role of a business, which later became one of the important parts of the CSR model created by Carroll (1991). This is because corporations create wealth according to society's demand and supply; hence, these organizations have reciprocal economic responsibilities (Claydon, 2011). Fadun (2014) analyzed the economic responsibilities of a corporation toward its employees, considering the stakeholders. The findings revealed that economic responsibility is considered as the most important dimension by stakeholders consistent with Carroll's (1991) CSR model (Fadun, 2014). Carmeli, Gilat, and Waldman (2007), based on a study conducted in Israel, argued that perceived social responsibility, i.e. the organization's focus on the development and quality of its products and services, which relates to economic responsibilities, enhances employee retention.

Meanwhile, corporations are expected to operate within the legal framework established by the government. This is important to ensure that companies are operating legally and fairly. Ganga (2012) discovered that in law-abiding and highly ethical companies, the employees are more likely to experience a higher sense of emotional attachment to the organization and tend to believe that remaining in the company is the right thing to do. This customization of CSR to the needs of the internal stakeholders could significantly contribute to an organizational commitment that can further engender other internal stakeholders and CSR-related outcomes, such as an increased retention among employees. On the other hand, corporate misdeeds or insignificant legal responsibilities have been shown to lead to negative individual-level outcomes, such as the inability to retain employees (Rupp, Aguilera, Ganapathi, \& Williams, 2013). Carroll (2009) mentioned that businesses are also expected to be responsible corporate citizens by complying with laws and regulations. By doing so, a favorable corporate and brand image is created on the top of employee retention (Turker, 2009). Besides, fair labor practices and safe working conditions were also highlighted as a measure of legal responsibilities; hence, these conditions lead to the retention of Gen $\mathrm{Y}$ employees (Pienaar, 2010).

Furthermore, the prominence of the ethical responsibility of a corporation also demonstrates a potential nexus between CSR and employee retention. The greater the fit of ethical responsibilities of CSR in the organization, the more it will lead to superior grounds for employee retention (Pienaar, 2010). Zunker (1994) identified that individuals choose an 
organization based on cultural values and vision and prefer if the organizational culture fits with their own values. For that reason, CSR programs frequently emphasize ethics and values. These can be clearly embedded in organizational strategies during the retention phase of employment. Evidence in a survey carried out by $\mathrm{PwC}$ (2011) revealed that Gen Y employees tend to desire companies that promote CSR. Peterson (2004) also found that the ethical dimension of CSR had the greatest influence on employees' decision to stay with their current employer. Jun and Seng (2016) also found that ethical responsibility activities help to accomplish some human resource management (HRM) objectives, such as maintaining ethical principles when interacting with major stakeholders. This can be strategically used in an organization as a powerful tool to attract and retain talents. The irresponsible behavior of a corporation toward the environment influences the employees' personal reputation, and ethical responsibilities affect employee retention (Pienaar, 2010).

Today's corporations must not only focus on profit but also on strong philanthropic responsibility to give back to the society and environment through activities, such as volunteering, donating and environmental protection. Bhattacharya, Sen, and Korschun (2008) found that employees' responses to CSR depend on characteristics of the individuals, the companies and the macro-environmental context of the industry, such as responsibility to the community or community involvement or community relations. Jun and Seng (2016) found that CSR activities help foster employment practices that enable employees to become socially involved. By volunteering, CSR can be strategically used in an organization as a powerful tool to attract and retain talents. Turker (2009) mentioned that the modern perspective on CSR emphasizes the society and NGOs, protection of the natural environment or the rights of future generations, which are important elements in retaining employees. Hence, the application of CSR could bring positive impacts on the retention of Gen $\mathrm{Y}$ employees in organizations.

\subsection{Generation $Y$}

Generational differences refer to individuals who are born in the same period and are influenced by a particular set of historical and cultural conditions (Hess \& Jepsen, 2009). Theorists such as Kupperschmidt (2000) and Smola and Sutton (2002) found that it is difficult to distinguish one generation from another; however, each generational group has a unique pattern of behavior based on its shared experiences (Hess \& Jepsen, 2009). Besides, it is also difficult to determine what age range belongs to which generation because different researchers have indicated different sets of age ranges (Queiri, Wan Yusoff, \& Dwaikat, 2014).

Hess and Jepsen (2009), however, argued that Gen Y refers to individuals born between 1980 and 2000, which is consistent with the classification of the Malaysian Department of Statistics regarding workforce ages (Queiri, Wan Yusoff, \& Dwaikat, 2015). This is supported by a prior research study by Loughlin and Barling (2001), which classified Gen Y individuals as those born after 1980. Numerous other studies also mentioned that Gen Y refers to individuals born between 1980 and 2000 (Cennamo \& Gardner, 2011; Main, 2017; PwC, 2011; Wallop, 2014; Wee, 2013). Gen Y is also referred to as the "Echo boomers," "nexters" or "Millennials" by different scholars (Graybill, 2014; Lamm \& Meeks, 2009). There are also other interpretations of age groups that belong to this generation, such as those born between 1980 and 1994 (Kumar \& Lim, 2008), 1981-1997 (Carnevale \& Fry, 2000), 1981-2000 (Lamm \& Meeks, 2009) and 1982-2002 (Graybill, 2014).

Gen $Y$, according to several large accounting firms, is important because this generation is responsible for shaping the world in the near future (Erickson, 2008), especially in maintaining the workforce in the accounting and finance sectors (Deloitte, 2017; PwC, 2011). In Malaysia, Gen Y consists of over $40 \%$ of the country's population (Wee, 2013). They are the 
REGE 27,4 new generation of the current workforce and it will be challenging for employers in terms of handling new work behavior and attitudes and coming up with tactics to retain them (Wee, 2013). A survey carried out by PricewaterhouseCoopers ( $\mathrm{PwC}$ ) in 2008 found that $88 \%$ of Gen Y employees look for employers that match their values, whilst $86 \%$ agree to leave employers that no longer meet their expectations. Thus, this shows the awareness and alertness of Gen $\mathrm{Y}$ on the importance of employer branding and CSR ( $\mathrm{PwC}, 2011)$. A research conducted by the Cone Millennial Cause group detailed in "The 2020 Workplace" found that $80 \%$ of a sample of 1,800 Gen $Y$ individuals wanted to work for a company that cares about how it impacts and contributes to society. More than half of the respondents said they would refuse to work for an irresponsible corporation. Hence, this indicates that Gen Y individuals care for and support CSR in organizations and are highly determinant of their employers (Meister, 2012). Baggott (2009) and Buchanan (2010) also found that Gen Y individuals are more compassionate and community service oriented/civic minded than other generations. Thus, employers need to understand the demand and work traits of this generation to grow along with these employees.

Furthermore, the Millennial Impact Report, which studied CSR's impact and retention in the Gen Y, found that $53 \%$ of Gen Y individuals surveyed are motivated at some point to work long term for companies whose mission was to make a difference in the world (Hayzlett, 2017). As echoed by Erickson (2008), Gen Y employees are highly aware of socially conscious brands that give back to the society, thus indicating responsible corporations. Gen $\mathrm{Y}$ individuals are described as the most socially conscious generation when compared to previous generations (Pienaar, 2010). Although Ohlrich (2011) found that CSR programs were not enough to retain Gen Y employees, CSR started to be gradually seen as a key component in retaining employees, particularly the millennials or Gen Y (Bhattacharya, Sen, \& Korschun, 2008).

According to Moore (2007), Gen Y individuals realize that corporations cannot survive without profit motivations or economic responsibilities. However, Gen Y individuals also believe that CSR can play a crucial role in fostering the ability of businesses to sustain their operations economically. In addition, Van Leeuwen (2010) asserted that Gen Y individuals would typically refuse to work for an irresponsible corporation. This suggests that a corporation should practice legal responsibilities, not only as part of CSR fulfillment but also as a good corporate citizen. In terms of ethics, Gen Y individuals are generally described to have integrity and awareness of business transparency (Wong, Wan, \& Gao, 2017); they are not motivated to work hard at an organization whose actions contradict its values (Jacobs, 2016); Gen Y individuals will likely use social media to expose companies that are deemed not fully transparent as well as companies that regard CSR as a public relations and marketing strategy (Rudominer, 2016). Gen Y individuals expect corporations to act according to the discourse, not only in terms of overall ethics but also regarding the perceived credibility and fairness of their management (Byrne, 2016). Furthermore, a study by the AMP Agency in 2010 found that $83 \%$ of Gen Y individuals will trust a company more if it is socially or environmentally responsible, whereas $79 \%$ want to work for a company that cares about how it impacts and contributes to society, and 64\% say a company's social or environmental activities drive their loyalty to that company (Van Leeuwen, 2010). Also, Gen Y individuals would be more motivated and committed at work if they feel that their employer has made a positive impact on the society (Jacobs, 2016).

Building on the arguments presented by Bhattacharya, Sen, and Korschun (2008), Hayzlett (2017), Pyszka and Gajda (2015), Stephenson (2009) and Wee (2013), this paper therefore intends to discover the impacts of CSR in retaining Gen Y employees in organizations. CSR in the context of this study is treated as a strategy that organizations could capitalize on in order to retain the services of Gen Y. Based on the abovementioned discussions, several hypotheses were developed and tested in order to meet the research's objectives. The hypotheses are as follows: 
H1. There is a relationship between economic responsibilities of CSR and employee retention in Gen Y.

H2. There is a relationship between legal responsibilities of CSR and employee retention in Gen Y.

H3. There is a relationship between ethical responsibilities of CSR and employee retention in Gen Y.

H4. There is a relationship between philanthropic responsibilities of CSR and employee retention in Gen Y.

\section{The research methodology}

This study employed a quantitative research method via questionnaires for the purpose of data collection. A questionnaire was constructed based on the five-point Likert scale. The questionnaire items were adapted from several past studies. The summary of the structure of the questionnaire is depicted in Table 1 below.

The target population was Gen Y accountants located in the Klang Valley areas (Selangor and Kuala Lumpur). The total population of Gen Y accountants in Klang Valley was 20,194. They were considered as a valuable pool of talented employees that need to be retained in accounting firms. The selection of the respondents was based on several preselected criteria: (1) Gen Y accountants who were born in Malaysia; (2) Gen Y accountants who were born between 1980 and 2000, as agreed by many scholars; (3) Gen Y accountants who are currently working in accounting firms in Klang Valley and (4) only employees who are under 37 years old were considered to be part of the Gen $Y$ age group. Based on the list of registered members of the MIA, most Gen Y accountants are based in Selangor $(12,941)$ and Kuala Lumpur $(7,253)$. The list of accounting firms operating in Klang Valley was obtained from the MIA. The purposive sampling technique was used to select the respondents based on the preselected criteria listed above. Hence, as suggested by Krejcie and Morgan (1970) in determining sample size, 377 respondents were required to reach the minimum sample size of this study.

In our study, the actual data collection aimed to obtain 377 responses from the respondents, which represents the adequate sample size for this study based on Krejcie and Morgan's (1970). The data were collected within six weeks from 12 October 2017 until 24 November 2017. Hence, starting from 12 October 2017, approximately 1,500 emails containing online forms of the questionnaire were sent to the accounting firms located in Klang Valley and 100 hard copies of the questionnaire were also distributed to the accountants based on information provided on the MIA website. However, out of the 1,500 online questionnaires sent out, only 366 responses were received. Furthermore, the respondents returned only 31 of the hard copy forms. Hence, a total of 1,134 online forms and 69 hard copy forms of the questionnaire were rejected.

Both data collection techniques showed an acceptance rate of $23.56 \%$, which is a low response rate. According to Fincham (2008), a response rate of at least $60 \%$ should be the goal for researchers; thus, in this current study, the response rate indicated a nonresponse bias of $76.44 \%$. The summary of response rate is provided in Table 2.

The highlights of the demographic profiles of the respondents are shown in Table 3. A total of 377 respondents were involved, composed of $165(43.8 \%)$ male and $212(53.2 \%)$ female accountants. Many respondents were Chinese (44.3\%), followed by Malays (40.1\%), Indians $(12.7 \%)$ and others $(2.9 \%)$. Most of the respondents hold a bachelor's degree $(88.1 \%)$, followed by a master's degree $(10.9 \%)$ and others $(1.1 \%)$. None of the respondents have diploma or doctorate.

The data obtained in this study were analyzed using SPSS. All the assessments of data normality, reliability and validity met the statistical requirements. The reliability test for each 
REGE 27,4

\section{8}

Table 1.

The summary of the structure of the questionnaire

\begin{tabular}{lll} 
No. Variable & Items & Sources \\
\hline &
\end{tabular}

1. Independent variables (CSR)

(1) Economic responsibilities

EC1: Company should produce high quality products and services that meet society's needs

EC2: Company should produce innovative products and services that improve society's 2

Turker (2009) well-being

EC3: Company must invest in Research \& Development that provides improvement in the value chain

EC4: Company should sell products that provide after-sales service to the customers

EC5: Company should sell all products at reasonable prices

EC6: Company should produce products that have long-term value for the customers

EC7: Company should design products and packaging that can be reused, repaired or recycled

(2) Legal responsibilities

L1: Company should perform in a manner consistent with the expectations of the government and law

L2: Company should be a law-abiding corporate citizen

L3: Company should provide goods and services that meet legal requirements

L4: Company must always pay taxes on a regular and continuous basis

L5: Company should respect consumer rights beyond legal requirements

L6: Company must provide safe working conditions based on employment law

L7: Company should provide full and accurate information about its products to the public

(3) Ethical responsibilities

ET1: Company should perform in a manner consistent with society's expectations and ethical norms

ET2: Company should recognize and respect ethical or moral norms adopted by society

ET3: Company should prevent ethical norms from being compromised in order to

achieve corporate goals

ET4: Company should have clearly defined code of ethics

ET5: Company must practice integrity and honesty

ET6: Company must practice openness or transparency

ET7: Company must be answerable for any of its actions

(4) Philanthropic responsibilities

P1: Company should contribute resources to the community

P2: Company should perform in a manner consistent with philanthropic and charitable expectations of society

P3: Company must voluntarily support projects that enhance the community's quality of life

P4: Company should implement programs to minimize negative impacts on the environment

P5: Company must make well-planned investments to avoid environmental degradation

P6: Company should make monetary contributions to charity and NGOs

P7: Company should make investments to create a better life for future generations

2. Dependent variable (employees' retention in Gen Y)

TR1: Work-life balance policies were implemented in this company

TR2: Employees who want to acquire additional education get support from this company

TR3: This company invests extensively in improving the levels of competency among the employees

TR4: This company encourages its employees to participate in volunteer activities

TR5: This company offers above average salary

TR6: Good promotion opportunities within the organization retain me in this company

TR7: This company practices social responsibilities

TR8: The company I work for gives me opportunities to utilize my skills and abilities

TR9: The management of my company is primarily concerned with employees' needs and wants

TR10: The managerial decisions related to the employees are usually fair
1 Toliver (2013)

$1 \quad$ Hartig (2014)

3 Self-developed items

$4 \quad$ Turker (2009)

$3 \quad$ Fadun (2014)

$1 \quad$ Turker (2009)

3 Toliver (2013)

3 Fadun (2014)

$4 \quad$ Turker (2009)

3 Fadun (2014)

8 Turker (2009)

$1 \quad$ Kyndt et al. (2009)

$1 \quad$ Hartig (2014) 
variable in this study was assessed via Cronbach's alpha coefficient. Based on the figures below, all constructs exceeded the recommended value of 0.70 (Nunnally, 1978). Hence, all constructs evidenced in Table 4 were highly reliable. As for the validity analysis, the KaiserMeyer-Olkin (KMO) measure, which verifies the sampling adequacy of this study, recorded a value of 0.922 , which is well above the minimum criterion of 0.5 (Kaiser, 1974). Bartlett's test of sphericity indicated a significance value of 0.00 . Table 4 below depicts the reliability results.

\section{Talent retention among \\ Generation Y}

379

\section{Findings of the study}

To answer the objectives of this paper, descriptive and inferential analyses were performed as highlighted in the following tables.

\subsection{Determination of the level of CSR awareness in accounting firms in the Klang}

Valley area

Table 5 below depicts the summary of the descriptive analysis for CSR. All the independent variables, namely, the CSR of economic, legal, ethical and philanthropic responsibilities show

\begin{tabular}{|c|c|c|c|c|c|}
\hline No. & $\begin{array}{l}\text { Type of } \\
\text { questionnaire }\end{array}$ & $\begin{array}{c}\text { Number of questionnaires } \\
\text { distributed }\end{array}$ & $\begin{array}{c}\text { Number of } \\
\text { questionnaires received }\end{array}$ & $\begin{array}{l}\text { Percentage }(\%) \text { of } \\
\text { acceptance rate }\end{array}$ & \\
\hline 1. & Online form & 1,500 & 366 & 24.4 & Table 2. \\
\hline \multirow[t]{2}{*}{2.} & Hard copy form & 100 & 31 & 31.0 & The summary of \\
\hline & Total & 1,600 & 377 & 23.56 & response rate \\
\hline
\end{tabular}

\begin{tabular}{|c|c|c|c|c|}
\hline Description of items & Category & Frequency* & Percentage $(\%)$ & \\
\hline \multirow{2}{*}{ Gender } & Male & 165 & 43.8 & \\
\hline & Female & 212 & 53.2 & \\
\hline \multirow[t]{4}{*}{ Race } & Malay & 151 & 40.1 & \\
\hline & Chinese & 167 & 44.3 & \\
\hline & Indian & 48 & 12.7 & \\
\hline & Others & 11 & 2.9 & \\
\hline \multirow[t]{5}{*}{ Educational background } & Diploma & 0 & 0 & \\
\hline & Bachelor's degree & 332 & 88.1 & \\
\hline & Master's degree & 41 & 10.9 & \\
\hline & Doctorate & 0 & 0 & \\
\hline & Others & 4 & 1.1 & \\
\hline \multirow[t]{4}{*}{ Position } & Junior associate & 108 & 28.6 & \\
\hline & Senior associate & 208 & 55.2 & Table 3. \\
\hline & Manager & 54 & 14.3 & The profile of \\
\hline & Others & 7 & 1.9 & respondents \\
\hline Variable/construct & No. of items & Cronbach's alpha & Reliability construct & \\
\hline CSR1: EC (economic) & 7 & 0.961 & Yes & \\
\hline CSR2: L (legal) & 7 & 0.958 & Yes & \\
\hline CSR3: ET (ethical) & 7 & 0.954 & Yes & Table 4. \\
\hline CSR4: P (philanthropy) & 7 & 0.978 & Yes & Reliability construct \\
\hline TR (employee retention) & 10 & 0.944 & Yes & using Cronbach's alpha \\
\hline
\end{tabular}


REGE 27,4

380 mean levels ranging between 3.7 and 5.0, which are high as indicated by Sekaran (2013). This shows that the response was high and close to 5 . Hence, all the variables showed high mean values for each CSR dimension (economic: 4.3634; legal: 4.5225; ethical: 4.6366; philanthropy: 4.2271). Thus, there is a high level of CSR awareness among the Gen Y employees operating in accounting firms in the Klang Valley area.

\subsection{Determination of the relationship between economic, legal, ethical and philanthropic} responsibilities and retention of Generation $Y$ employees

A correlation analysis was employed to test the hypotheses developed in this study, as depicted in Table 6. The subsequent discussion provides detailed outcomes of the analysis.

It was found that the relationship between economic responsibility (IV1:EC) and employee retention of Gen Y accountants (DV:TR) is moderate and significant $\left(r=0.316^{* *}, p<0.05\right)$. Sekaran (2013) mentioned that a correlation between 0.30 and 0.49 shows a moderate correlation. The result thus serves as evidence to support the existence of a significant relationship between economic responsibility and employee retention of Gen Y accountants. Therefore, $\mathrm{H} 1$ is accepted.

Next, the relationship between legal responsibility (IV2:L) and retention of Gen Y accountants (DV:TR) was found to be significant $\left(r=0.283^{* *}, p<0.05\right)$. Sekaran (2013) mentioned that correlation values between 0.20 and 0.29 indicate a weak or low correlation. The result thus serves as evidence to support the existence of a significant relationship between legal responsibilities of CSR and employee retention in the Gen Y accountants. Therefore, $\mathrm{H} 2$ is accepted.

The findings of the study also revealed that the relationship between ethical responsibility (IV3:ET) and employee retention of Gen Y accountants (DV:TR) is low or weak but significant $\left(r=0.264^{* *}, p<0.05\right)$. The result thus serves as evidence to support the existence of a significant relationship between ethical responsibilities of CSR and employee retention of Gen $\mathrm{Y}$ accountants. Therefore, $\mathrm{H} 3$ is accepted.

Finally, the results also indicate that the relationship between philanthropic responsibility (IV4:P) and retention of Gen Y employees (DV:TR) is moderate but significant $(r=0.354 * *$, $p<0.05)$. The result thus serves as evidence to support the existence of a significant relationship between philanthropic responsibilities of CSR and employee retention of Gen Y

\section{Table 5.}

The summary of the descriptive analysis for corporate social responsibility

\begin{tabular}{lllllll}
\hline Variable & $N$ & Min & Max & Mean & SD & Interpretation \\
\hline IV1:EC & 377 & 3.00 & 5.00 & 4.3634 & 0.45900 & High \\
IV2:L & 377 & 3.00 & 5.00 & 4.5225 & 0.46670 & High \\
IV3:ET & 377 & 3.00 & 5.00 & 4.6366 & 0.44677 & High \\
IV4:P & 377 & 2.71 & 5.00 & 4.2271 & 0.49837 & High \\
\hline
\end{tabular}

Table 6.

Pearson's correlation coefficient

\begin{tabular}{lclcccr}
\hline Variable & Mean (SD) & \multicolumn{1}{c}{1} & 2 & 3 & 4 & 5 \\
\hline DV:TR & $4.1854(0.46199)$ & 1 & - & - & - & - \\
IV1:EC & $4.3634(0.45900)$ & $0.316^{* *}$ & 1 & - & - & - \\
IV2:L & $4.5225(0.46670)$ & $0.283^{* *}$ & $0.409^{* *}$ & 1 & - & - \\
IV3:ET & $4.6366(0.44677)$ & $0.264^{* *}$ & $0.475^{* *}$ & $0.442^{* *}$ & 1 & - \\
IV4:P & $4.4271(0.49837)$ & $0.354^{* *}$ & $0.554^{* *}$ & $0.490^{* *}$ & $0.425^{* *}$ & 1
\end{tabular}

Note(s): *significant $(p<0.05) ; * *$ very significant $(\phi<0.01)$ 
accountants. Therefore, H4 is accepted. Table 7 summarizes the results of the hypothesis testing.

\subsection{Examination of the effect of Carroll's corporate social responsibility dimensions on the retention of Generation Y employees}

A multiple regression analysis was performed to examine the effect of Carroll's CSR dimensions on the retention of Gen Y employees. Table 8 below summarizes the results of the multiple regression analysis.

As depicted in Table 8 , the $R$-value is 0.400 , while the $R$-square value is 0.160 and the overall model fit is $16 \%$. According to Hair, Black, Babin, and Anderson (2010), an $R$-square value ranging from 0.10 to 0.25 explains a low variance on the extent of variance explained by the model. Hence, the CSR dimensions, namely, economic, legal, ethical and philanthropic responsibilities as predictors of employee retention of Gen $\mathrm{Y}$ accountants only account for $16 \%$ of the research model, whereas the remaining $84 \%$ could be explained by other factors.

The significance value derived from the ANOVA indicates the absolute fit of the model because the significant value is 0.000 ( $p$-value $<0.01)$. Meanwhile, the standardized beta values indicate the importance of each predictor (independent variable), considering that the higher the value, the more equivalent it is to the importance of the predictor (Field, 2015). Furthermore, the significant contribution of each independent variable in predicting the outcome can be observed when the value of significance is less than 0.05 , which is regarded as significant (Field, 2015).

The model revealed that philanthropic (IV4:P) and economic responsibilities (IV1:EC) are significant predictors of employee retention of Gen Y accountants (DV:TR). The beta value for both predictors are $B=0.204, p=0.001<0.05$ and $B=0.128, p=0.035<0.05$, respectively. Meanwhile, legal (IV2:L) and ethical responsibilities (IV3:ET) are not significant

\begin{tabular}{lll}
\hline No. & Hypothesis & Results \\
\hline H1 & $\begin{array}{l}\text { There is a relationship between economic responsibilities of CSR and employee retention in } \\
\text { Gen Y }\end{array}$ & Accepted \\
H2 & $\begin{array}{l}\text { There is a relationship between legal responsibilities of CSR and employee retention in Gen } \\
\text { Y }\end{array}$ & Accepted \\
H3 & $\begin{array}{l}\text { There is a relationship between ethical responsibilities of CSR and employee retention in } \\
\text { Gen Y }\end{array}$ & Accepted \\
H4 & $\begin{array}{l}\text { There is a relationship between philanthropic responsibilities of CSR and employee } \\
\text { retention in Gen Y }\end{array}$ & Accepted
\end{tabular}

\section{Talent retention among \\ Generation Y}

381

\begin{tabular}{lcc}
\hline Variables & Beta & Significance \\
\hline Economic responsibilities of CSR (IV1:EC) & 0.128 & 0.035 \\
Legal responsibilities of CSR (IV2:L) & 0.098 & 0.089 \\
Ethical responsibilities of CSR (IV3:ET) & 0.073 & 0.202 \\
Philanthropic responsibilities of CSR (IV4:P) & 0.204 & 0.001 \\
$R=0.400$ & & \\
$R^{2}=0.160$ & & \\
Significance $=0.000$ & & \\
$F$-value $=17.707$ & & \\
Durbin Watson $=1.675$ & &
\end{tabular}

Table 7.

The summary of hypotheses testing results multiple regression analysis 
REGE

27,4

382

predictors of employee retention of Gen Y accountants (DV:TR). The beta value for both predictors are $B=0.098, p=0.089<0.05$ and $B=0.073, p=0.202<0.05$, respectively.

Philanthropic responsibility is the main influential predictor of employee retention, followed by economic responsibility. Although the correlation analysis in Table 6 shows a very significant relationship, the multiple regression analysis further defines the significance of the relationship in the form of effect size. Thus, only philanthropic and economic responsibilities have a positive and significant relationship with employee retention of Gen $\mathrm{Y}$ accountants.

\section{Discussion of the study}

\subsection{The level of corporate social responsibility awareness in accounting firms in the Klang} Valley area

The result of this study concurs with that of prior studies by Duff and Guo (2010), Edgley, Sharma, and Anderson-Gough (2016), Sujana (2014) and Tilt (2009). Sujana (2014) maintained that the concept of CSR is not something that is totally ignored by accounting firms and that they practice CSR activities according to their firms' size and needs. This is because accounting firms are divided into different categories such as micro, small and medium sizes and the Big-4 firms. The most cited Big-4 firms include Deloitte, KPMG, PwC and EY (Edgley, Sharma, \& Anderson-Gough, 2016). Micro-sized firms' CSR-based activities are largely related to their employees, while small-sized firms' CSR activities are based on their employees and clients. Medium-sized firms' CSR activities tend to support the development of long-term strategies with high net worth clients.

Other than that the Big-4 firms were reported to have a high level of awareness toward CSR practices through CSR reporting and CSD by disclosing CSR activities in their annual reports and company's website (Duff \& Guo, 2010). They also refer to CSR according to their needs. For example, Deloitte considers CSR as corporate responsibility and sustainability. EY and $\mathrm{PwC}$ refer to CSR as corporate responsibility, whereas KPMG use the term CSR in their organization. Moreover, the nature of activities of the accounting firms that operate within public interest made them closer to CSR and more aware of the practices. Moreover, the business activities of accounting firms involved in CSR-related service line also contribute to the idea of employing CSR in the organization (Duff \& Guo, 2010).

Tilt (2009) also found that although the accounting standard does not explicitly design a role for accountants in CSR, the profession and the way it deals with CSR reporting demonstrates how the sector is closely related to social responsibility. With respect to Gen Y, Sabrina (2017) found that CSR awareness is high among this new generation. Thus, organizations also need to focus on the growing demand for CSR.

\subsection{The relationship between economic, legal, ethical and philanthropic responsibilities and retention of Generation $Y$ employees}

The results obtained in the study revealed that there is a significant relationship between all the aspects of CSR, namely, economic, legal, ethical and philanthropic responsibilities and employee retention of Gen Y accountants. A past study by Fadun (2014) revealed that economic responsibility has a significant relationship with employee retention. In addition, economic responsibility was also deemed as the most important aspect by stakeholders, which is in accordance with Carroll's (1991) CSR model (Fadun, 2014). Moreover, this finding conforms to the notion by Carmeli, Gilat, and Waldman (2007) that perceived social responsibility, i.e. the organization's focus on the development and quality of products and services that relate to economic responsibilities enhances employee retention. Furthermore, Erickson (2008) stated that Gen Y employees are highly aware of socially responsible brands 
that give back to the society. Pienaar (2010) strengthened the argument that there is a significant relationship between economic responsibility and retention of Gen Y employees.

With respect to legal responsibility, there is a significant relationship to be found with retention of Gen Y employees. The finding is consistent with that of Ganga (2012), which indicated that, in law-abiding and highly ethical companies, employees are prone to experience a higher sense of emotional attachment to the organizations and believe that staying on with the company is the right thing to do. The customization of CSR to the needs of internal stakeholders could significantly contribute to organizational commitment that can further engender other internal stakeholders and CSR outcomes, such as increased employee retention. This finding is also consistent with that of Campbell (2007) and Pienaar (2010), who stated that an emphasis on legal responsibilities can lead to the retention of Gen Y employees. This study also supports the claim by Rupp, Aguilera, Ganapathi, and Williams (2013) that corporate misdeeds or insignificant legal responsibilities can lead to negative individual-level outcomes such as the inability to retain employees.

Our study also proves a significant relationship between ethical responsibility and employee retention of Gen Y consultants. The finding is in line with that of Peterson's (2004), which found that the ethical dimension of CSR had the greatest influence on the employees' decision to stay with their current employing organizations. Besides, this finding is also in line with that of Jun and Seng's (2016), which stated that ethical responsibility activities facilitate the accomplishment of some HRM objectives, such as maintaining ethical principles of the organization when interacting with major stakeholders. This can be strategically used in an organization as a powerful tool to attract and retain talents. Furthermore, the irresponsible behavior of a corporation toward the environment influences the employees' personal reputation, where it was found that ethical responsibility affects the retention of employees, as found by Pienaar (2010).

Finally, this study maintains that there is a significant relationship between philanthropic responsibilities and retention of Gen $\mathrm{Y}$ employees. The findings of this study support other research studies on the effect of CSR in retaining employees, where only selected dimensions of CSR, such as responsibility to the community or philanthropic responsibilities, impact employee retention. Jun and Seng (2016) found that CSR activities foster employment practices that enable employees to become socially involved through CSR volunteerism. This can be strategically used in an organization as a powerful tool to attract and retain talents. According to McGuire (2004), Gen Y has been inculcated with a sense of responsibility toward themselves, their neighbors, their communities and the planet. Moreover, McGuire (2004) argued that Gen Y grew up learning the importance of recycling and using less water and that their actions affect their communities directly. Resultantly, Gen Y believes that their employers also have a responsibility toward the society and the environment.

\subsection{The effect of Carroll's corporate social responsibility dimensions on the retention of Generation $Y$ employees}

Interestingly, the advanced multiple regression analysis on the effect of Carroll's (1991) CSR dimensions on employee retention of Gen Y accountants revealed interesting and mixed findings, which are inconsistent with the findings derived from the correlation analysis. As a correlation analysis can only test the relationship between variables (i.e. IV and DV), a multiple regression analysis produces more powerful results as it can test all the variables identified comprehensively as the model of the study. It was found that the interaction of the four CSR dimensions only pose a $16 \%$ influence on employee retention of Gen Y accountants. This is probably because only two out four CSR dimensions impact the retention of Gen Y employees.

This study found that only philanthropic and economic responsibilities have a positive and significant relationship with employee retention of Gen Y consultants. Philanthropic 
REGE 27,4

\section{4}

responsibilities are ranked highest in Carroll's (1991) pyramid of CSR. Many literature reviews have pointed out that philanthropic responsibility seems to be the most significant predictor of employee retention. This is evident in Deloitte's Global Millennial Survey 2014, which stated that $63 \%$ of Gen Y individuals donate to charity, $43 \%$ actively volunteer or are members of community organizations and $52 \%$ have signed petitions related to natural environment protection (Sammut, 2014). Sammut (2014) also mentioned that Gen Y individuals particularly care about social equality, environmental sustainability, education, health and human rights. Gen Y is highly inclined to benevolence. A survey carried out by PwC in "Think Sustainability-The Millennials View" as well as Deloitte's "The 2016 Deloitte Millennial Survey" concluded that $92.1 \%$ of surveyed Gen Y individuals opined that working for an environmentally and socially responsible company is important. From this we see that Gen $\mathrm{Y}$ individuals seem to appreciate philanthropic responsibilities more than other responsibilities (Moore, 2007). The concept of CSR is no longer associated with only charity; rather, it goes beyond that to include contributions toward organizational sustainability (Enquist, Edvardsson, \& Sebhatu, 2008).

With respect to economic responsibilities, this study proves that it has a significant impact on employee retention of Gen Y accountants. According to Moore (2007), CSR could foster economic sustainability for firms as Gen Y employees realize that corporations could not survive without profit motivations or economic responsibilities. Corporations have the responsibility to increase their profits based on the argument that the purpose of business is solely for safeguarding the interests of shareholders. This viewpoint is absolutely inseparable from the primary role of business, which later became one of the important aspects of the CSR model created by Carroll (1991). This is because corporations create wealth based on society's demand and supply; hence, these organizations have economic responsibilities (Claydon, 2011). Like accounting firms that are considered as business entities that generate profit but with limited liability partnership, the economic responsibilities still exist and are significant to Gen $\mathrm{Y}$ individuals.

The findings of the study also found that legal and ethical aspects were not significant in predicting employee retention of Gen $\mathrm{Y}$ accountants. The results contradict the nature of this profession that is highly ruled by the MIA, which emphasizes high integrity and professionalism among accountants via compliance to the Accountants Act 1967 and code of professional conduct. According to the MIA website, the Revised By-Laws (On Professional Ethics, Conduct and Practice) of the MIA are issued pursuant to Section 10(a) of the Accountants Act 1967 and is binding on all members of the MIA. The Malaysian code, which binds Malaysian accountants, was adapted from the Code of Ethics for Professional Accountants of the International Ethics Standards Board for Accountants (IESBA), published by the International Federation of Accountants (IFAC). Although Pienaar (2010) found that legal responsibilities of CSR can facilitate employee retention, the current study discovered otherwise.

Furthermore, this profession is also governed by the code of ethics issued by MIA that must be adhered to by accountants. Accountants, especially those from accounting firms which operate in public interest to oversee the conduct of corporations, are expected to perform better in terms of skills, objectivity, independence and integrity (Bakar, Saat, \& Majid, 2003). The framework for the desirable conduct of accountants and an ethical work environment that enforces the Gen Y employees' intention to keep on working at their current firms is somehow not clear based on the findings of this study. Even though Jun and Seng (2016) found that the ethical dimension of CSR had the greatest influence on employee retention, the findings of our study suggests otherwise. A possible justification for the insignificant impact of both legal and ethical responsibilities on employee retention of Gen $\mathrm{Y}$ accountants is probably due to the mandatory requirements set by the Malaysian authority, especially Bursa Malaysia, which is under the purview of the Securities Commission and the 
Ministry of Finance. Bursa Malaysia enforces strict and high standards of corporate governance practices as guided by the Malaysian Code of Corporate Governance. Companies are also required to meet the provisions set by the Companies Commission of Malaysia, a statutory body that regulates companies and businesses via strict compliance, comprehensive enforcement and monitoring activities to sustain positive developments in the corporate and business sectors in Malaysia. These two dimensions seem to project less of the social element of corporate responsibility that is expected from the organizations. Both lack voluntary elements as compared to the economics and philanthropic responsibilities.

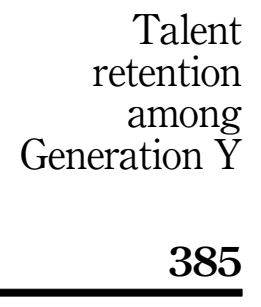

\section{Limitations of the study}

There are several limitations to this research. The first one is related to Carroll's (1991) pyramid of CSR from which the independent variables of this current research were adapted, namely, economic, legal, ethical and philanthropic responsibilities. Since there are various other concepts and models of CSR, the findings of this study may only be applicable to certain circumstances relevant to Carroll's (1991) CSR dimensions. Thus, this study is limited to the abovementioned dimensions.

The second limitation of this study is related to the study's subject i.e. Gen Y. The unit of analysis of our study was Gen Y individuals who are working as accountants in accounting firms in the Klang Valley area. Thus, generalizations cannot be made to other populations outside this area. Moreover, the findings of our study are only applicable and relevant to this generation and possibly the future generation. Hence, this limits the understanding of the workplace attitudes of previous generations such as Gen $\mathrm{X}$ and baby boomers.

Finally, our study is limited to only one sector. We only examined accountants operating in accounting firms and thus, the findings are not applicable to managers and top management of other industries. Hence, the application and relevance of the findings of this study to other professions cannot be inferred as different individuals have different inferences and perceptions added to their educational background and profession.

\section{Recommendations for future research}

The recommendations for future research were formed based on several limitations encountered by the researcher throughout the course of this inquiry. Future research on a similar topic is recommended to provide better understanding of the research outcomes. This study was initiated based on prior literature reviews in which the main purpose was to investigate Carroll's (1991) CSR pyramid entailing the dimensions of economic, legal, ethical and philanthropic responsibilities and their effect on employee retention of Gen $\mathrm{Y}$ accountants. Such inquiry is significant as Gen Y employees who are currently dominating the workforce bring different work attitudes and values that astonish the management and academicians. Hence, more in-depth research needs to be done to identify other factors that lead to the retention of this generation in their organizations.

The limitation of our study can be resolved by conducting an in-depth study to identify other perceptions and motivating factors that influence the intention of accountants to remain in their current organizations using different concepts and models of CSR. Besides, future research needs to be done to obtain more information about the workplace attitudes and values of Gen $Y$ individuals and other generations. In addition, the model of the study could be expanded to cover more regions in Malaysia, namely, the southern, northern, eastern and Borneo regions. This is important to gain more significant outcomes.

Moreover, future studies can also focus on other sectors such as the manufacturing or oil and gas industries, which are more aware of CSR practices and strategies. This can provide more significant outcomes toward understanding the relationship between CSR and the 
REGE 27,4

retention of Gen $\mathrm{Y}$ employees in such industries. The researcher can thus understand more about CSR application in different industries and widen the judgment on the importance of CSR for corporations.

\section{Conclusion}

This research is significant in gauging CSR practices in organizations and their impact on employee retention, especially of Gen Y accountants. As CSR has a significant link with employee retention, corporations must be alert that Gen Y employees are highly aware of CSR practices conducted by their organizations. Corporations must employ CSR practices in their organizations in order to pursue organizational sustainability and higher performance (Bhattacharya, Sen, \& Korschun, 2008).

The accounting firms in the Klang Valley area show a significant level of CSR awareness among their Gen Y employees. The Gen Y accountants in these firms were found to place a high value on all levels of CSR dimensions. The findings also indicate that there is a positive relationship between economic, legal, ethical and philanthropic responsibilities and employee retention of Gen Y accountants across the accounting firms in the Klang Valley area.

The findings derived from the study also revealed that Malaysian Gen Y employees, especially accountants working in accounting firms in the Klang Valley area, place philanthropic responsibility as the most significant predictor of employee retention exercise or practices, followed by economic responsibility. This is an interesting finding as it contradicts the study conducted by Carroll (1991), which pointed out that the total CSR of a business entail the simultaneous fulfillment of economic, legal, ethical and philanthropic responsibilities. Hence, our study challenges Carroll's (1991) CSR pyramid with respect to the factors contributing to employee retention, particularly regarding Gen Y employees. The contradicting findings obtained in our study pose a new challenge for future research in contesting Carroll's (1991) views on the simultaneous impact of the CSR dimensions. The current findings, however, cannot be generalized to other professions due to differences in geographic locations, sectors, as well as personalized and unique views on the CSR concept.

The important conclusion in this study is that employers need to understand the impact of their employee retention practices regarding Gen $Y$ employees, who are currently dominating the workforce after Gen X. In less than a decade, Gen Y will dominate the workforce; hence, this generation will assume significant positions such as managers, corporate leaders and other related positions in many organizations. Although Gen $\mathrm{Y}$ also shows a high degree of awareness toward CSR, organizations must be quick to respond to CSR factors that are paramount in retaining them at the workplace. This could further strengthen their CSR activities and practices as Gen Y shows a significant awareness on all levels of CSR.

\section{References}

Aguilera, R.V., Rupp, D., Williams, C.A., \& Ganapathi, J. (2007). Putting the S Back in corporate social responsibility: A multi-level theory of social change in organizations. Academy of Management Review, 32, 836-863.

Aguinis, H., \& Glavas, A. (2012). What we know and don't know about corporate social responsibility. Journal of Management, 38(4), 932-968.

Aguinis, H., \& Glavas, A. (2013). Embedded vs peripheral corporate social responsibility: Psychological foundations. Industrial and Organizational Psychology, 6(4), 314-332.

Baden, D. (2016). A reconstruction of Carroll's pyramid of corporate social responsibility for the 21st century. International Journal of Corporate Social Responsibility, 1(1), 8.

Baggott, C.A. (2009). If we build it, they will come. National Civic Review, 98(3), 30-33. 
Bakar, M.A., Saat, M.M., \& Majid, A.A. (2003). Ethics and the accounting profession in Malaysia. Journal of Financial Reporting and Accounting, (January 2003), doi: 10.1108/19852510380000502.

Bhattacharya, C.B., Sen, S., \& Korschun, D. (2008). Using corporate social responsibility to win the war for talent. MIT Sloan Management Review, 49(2), 37-44, doi: 10.1007/s10551-008-9812-2.

Boersma, M. (2014). Accountants: Your country needs you. The Financial Times. Available from: https://www.ft.com/content/5c5a8508-432e-11e4-8a43-00144feabdc0.

Bouvain, P., Baumann, C., \& Lundmark, E. (2013). Corporate social responsibility in financial services: A comparison of Chinese and east. International Journal of Bank Marketing, 31(6), 420-439.

Buchanan, L. (2010). Meet the Millennials. Journal of Human Resource, 32(7), 166.

Byrne, B.M. (2016). Structural Equation Modelling with AMOS: Basic Concepts, Applications and Programming, 3rd ed., Routledge, New York, NY.

Campbell, J.L. (2007). Why would corporations behave in socially responsible ways? An institutional theory of corporate social responsibility. Academy of Management Review, 32(3), 946-967.

Carmeli, A., Gilat, G., \& Waldman, D.A. (2007). The role of perceived organisational performance in organisational identification, adjustment and job performance. Journal of Management Studies, 44(6), 972-992.

Carnevale, A.P., \& Fry, R.A. (2000). Crossing the great divide: Can we achieve equity when generation $\{Y\}$ goes to college? Leadership 2000 series, Educational Testing Service, Princeton, NJ.

Carroll, A.B. (1991). The pyramid of corporate social responsibility: Toward the moral management of organisational stakeholders. Business Horizons, 34, 39-48, doi: 10.1177/0312896211432941.

Carroll, A.B. (1999). Corporate social responsibility; evolution of a definitional construct. Business \& Society, 38, 268-295.

Carroll, A.B. (2009). A history of corporate social responsibility: Concepts and practices. In A. Crane et al. (Eds), The Oxford Handbook of Corporate Social Responsibility, Oxford University Press, 2008, 19-46.

Cennamo, L., \& Gardner, D. (2011). Generational differences in work values, outcomes and person-organisation values fit. IEEE Engineering Management Review, 39(2), 24-36, doi: 10.1109/EMR.2011.5876170.

Chin, M.Y., Lau, K.H., Leong, Y.B., Lim, Y.C., \& Yip, K. (2013). Key Retention Factors: An Empirical Study on Accounting Employees in Accounting Firms in Klang Valley. Malaysia: Universiti Tunku Abdul Rahman, Available from: http://eprints.utar.edu.my/id/eprint/1111.

Claydon, J. (2011). A new direction for CSR: The shortcomings of previous CSR models and the rationale for a new model. Social Responsibility Journal, 7(3), 405-420.

Cofer, D. (2010). Sector based talent: Attraction and retention. Economic Development Journal, 9(2), 40-45.

Cooke, F.L., \& He, Q. (2010). Corporate social responsibility and HRM in China: A study of textile and apparel enterprises. Asia Pacific Business Review, 16(3), 355-376.

Cooper, P. (2015). What Malaysians Value Most About Work, Available from: https://www. michaelpage.com.my/advice/market-insights/industry-reports/what-malaysians-value-mostabout-work.

Deloitte (2017). A belief in business. . but could do more, Available from: www.deloitte.com.

Duff, A. (2016). Corporate social responsibility reporting in professional accounting fi rms. The British Accounting Review, 48(1), 74-86.

Duff, A., \& Guo, X. (2010). Corporate social responsibility and the professional accounting firm: Insights from firms' disclosures. Centre for Business Performance ICAEW, Available from: https://www.icaew.com/-/media/corporate/files/products/sustainability/tecpln9787-crs-briefing16-dec-final.ashx.

Dusuki, A.W., \& Tengku Mohd Yusof, T.F.M. (2008). The pyramid of corporate social responsibility model: Empirical evidence from Malaysian stakeholder perspectives. Malaysian Accounting Review, 7(2), 29-54.

\section{Talent retention among \\ Generation Y}

387 
REGE 27,4

\section{8}

Edgley, C., Sharma, N., \& Anderson-Gough, F. (2016). Diversity and professionalism in the Big four firms: Expectation, celebration and weapon in the battle for talent. Critical Perspectives on Accounting, 35, 13-34.

Enquist, B., Edvardsson, B., \& Sebhatu, S.S. (2008). Corporate social responsibility for charity of for service business? Asian Journal on Quality, 9(1), 55-67.

Erickson, T.J. (2008). Plugged in: The Generation Y Guide to Thriving at Work. Boston: Harvard Business Press.

Fadilah, P., Maniam, K., \& Nafis, A. (2015). Assessing gen Y impact on organisational performance: An analysis from top management perspective. Journal of Administrative Science, 12(1), 47-59.

Fadun, S.O. (2014). Corporate social responsibility (CSR) practices and stakeholders expectations: The Nigerian perspectives. Research in Business and Management, 1(2), 13, doi: 10.5296/rbm. v1i2.5500.

Ferreira, P., \& Real de Oliveira, E. (2014). Does corporate social responsibility impact on employee engagement?. Journal of Workplace Learning, 26(3/4), 232-247.

Field, A.. (2015). Discovering Statistics using IBM SPSS Statistics (4th ed.). Singapore: SAGE Publications Asia-Pacific Pte.

Fincham, J.E. (2008). Response rates and responsiveness for surveys, standards, and the Journal. American Journal of Pharmaceutical Education, 72(2), 43.

Foong, M.L., Joy, S.H.M., Lim, E.Z., Phang, Z.B., \& Tiong, X.Y. (2015). Talent Retention: A Study in Malaysia Manufacturing Industry. Malaysia: Universiti Tunku Abdul Rahman, Available from: http://eprints.utar.edu.my/1791/1/Talent-Retention-A-study-in-Malaysia-ManufacturingIndustry.pdf.

Ganga, S.D. (2012). The view from within: Internal publics and CSR. Journal of Communication Management, 16(1), 39-58.

Gering, J., \& Conner, J. (2002). A strategic approach to employee retention. Healthcare Financial Management, (November). 40-44.

Glavas, A. (2016). Corporate social responsibility and employee engagement: Enabling employees to employ more of their whole selves at work. Frontiers in Psychology, 7(796), 1-10. doi: 10.3389/ fpsyg.2016.00796.

Gomes, M. (2017). Auditors get to grips with new challenges Delegates at a seminar hosted by ACCA and the Malaysian Institute of Accountants heard that auditors must embrace the challenges posed by globalisation and technology. ACCA, 1-8, Available from: http://www.accaglobal. $\mathrm{com} /$.

Graybill, J.O. (2014). Millennials among the professional workforce in academic libraries: Their perspective on leadership. Journal of Academic Librarianship, 40(1), 10-15, doi: 10.1016/j.acalib. 2013.09.006.

Hair, J., Black, W., Babin, B., \& Anderson, R. (2010). Factor Analysis. Mutivariate Data Analysis-A Global Perspective, Pearson Education, Upper Saddle River, NJ, 91-151.

Hartig, S. (2014). Winning the War for Talent: Does CSR Matter in the Recruitment Process?, Masters Thesis, Nova School of Business and Economics, Available from: https://run.unl.pt/bitstream/ 10362/11780/1/Hartig_2014.pdf.

Hayfaa, A.T., Pascal, M. and Mahrane, H. (2017). Talent retention: Evidence from a multinational firm in France. Employee Relations, 39(4), 426-445, doi: 10.1108/ER-07-2016-0130.

Hayzlett, J. (2017). 4 ways employers are using corporate social responsibility to recruit millennials. Entrepreneur Asia Pacific, Available from: https://www.entrepreneur.com/article/285587.

Heinrich, E. (2017). Overcoming regional retention issues: How some Michigan organisations use CSR to attract and engage top talent. Corporate Social Responsibility, Sustainability, and Ethical Public Relations: Strengthening Synergies with Human Resources, Emerald Publishing, 89-122, doi: 10.1108/978-1-78714-585-620181004. 
Hess, N., \& Jepsen, D.M. (2009). Career stage and generational differences in psychological contracts. Career Development International Journal, 14(8), 261-283, doi: 10.1108/13620430910966433.

Holland, P., Sheehan, C., Donohue, R., \& Pyman, A. (2007). Contemporary Issues and Challenges in $H R M$. Tilde University Press, Prahran.

Ibrahim, S.N., \& Zayed, A. (2018). The impact of the intergrated talent management on the competitive advantage in multinational corporations. International Journal of Academic Research in Business and Social Sciences, 8(7), 221-237.

Jacobs, K. (2016). The importance of work with purpose for Gen Y. HR Magazine, Available from: https://www.hrmagazine.co.uk/article-details/the-importance-of-work-with-purpose-forgen-y.

Jun, W.W., \& Seng, L.C. (2016). The relationship of corporate social responsibility and employee retention. International Journal of Economics, Commerce and Management, IV(10), 911-921.

Kaiser, H.F. (1974). An index of factorial simplicity. Psychometrika, 39, 31-36, doi: 10.1007/BF02291575.

Karunathilaka, S.K.G.G., Ab Yajid, M.S., \& Khatibi, A. (2016). The HR strategies impact of talent retention on performance of private sector organisations in Sri Lanka. European Journal of Research in Social Sciences, 4(6), 73-83.

Krejcie, R.V., \& Morgan, D.W. (1970). Determining sample size for research activities. Educational and Psychological Measurement, 30, 607-610.

Kumar, A., \& Lim, H. (2008). Age differences in mobile service perceptions: Comparison of generation Y and baby boomers. Journal of Services Marketing, 22(7), 568-577, doi: 10.1108/ 08876040810909695.

Kupperschmidt, B.R. (2000). Multigeneration employees: Strategies for effective management. The Health Care Manager, 19, 65-76.

Kyndt, E., Dochy, F., Michielsen, M. and Moeyaert, B. (2009). Employee retention: Organisational and personal perspectives.Vocations and Learning, 2(3), 195-215.

Lamm, E., \& Meeks, M.D. (2009). Workplace fun: The moderating effects of generational differences. Employee Relations, 31(6), 613-631, doi: 10.1108/01425450910991767.

Loughlin, C., \& Barling, J. (2001). Young workers' work values, attitudes, and behaviours. Journal of Occupational and Organisational Psychology, 74(4), 543-558, doi: 10.1348/096317901167514.

Ma, E., Qu, H., \& Eliwa, R.A. (2012). The effect of corporate social responsibility on customers. Hospitality Review, 2, 513-535.

Main, D. (2017). Who are the Millennials?, Available from: http://www.livescience.com/38061millennials-generation-y.html.

McGuire, A. (2004). Engaging Millennial Employees: Recruit and Retain Top Talent with Cause, Available from: http://ww1.prweb.com/prfiles/2014/01/27/11526003/Network-for-GoodMillennial-Engagement.pdf.

McWilliam, A., \& Siegel, D. (2001). Corporate social responsibility: A theory of the firm perspective, Academy of Management Review, 26(1), 117-127.

Meister, J. (2012). The Future of Work: Corporate Social Responsibility Attracts Top Talent. Forbes, 11-13, Available from: https://www.forbes.com.

Michael Page Malaysia (2015a). 2015 Employee Intentions Report Malaysia. Michael Page, Available from: http://www.michaelpage.com.sg/sites/michaelpage.com.sg/files/2015_SGMP_ EMPLOYEE_INTENTIONS_FINAL_0.pdf.

Michael Page Malaysia (2015b). Employee Intentions Report Malaysia. Michael Page, Available from: http://www.michaelpage.com.sg.

Moore, A. (2007). Generation $Y$ and CSR: what is their attitude?, Available from: https:// millennialsthinktank.files.wordpress.com/2011/02/amended-dissertation-for-frog-and-amy-1.pdf. 
REGE 27,4

Mushtaq, N. (2013). Paramount role of corporate social responsibility in retaining employees and corporate reputation: An extract from Pakistan's banking sector. Journal of Business and Finance, 1(3), 126-138.

Nasir, N.M., Ghani, E.K., \& Said, J. (2009). Why do not accounting graduates want to become accountants?. Journal of Modern Accounting and Auditing, 5(5), 59-65.

Noor Emilina, M.N., Nurul Akmal, A.H., Nur Raihana, M.S., Nur Syuhada, J., \& Nurul Fatma, A. (2015). Corporate social responsibility: An overview from Malaysia. Journal of Applied Environmental and Biological Sciences, 4(2015), 82-87.

Nunnally, J.C. (1978). Psychometric Theory. New York, NY: McGraw Hill.

Ohlrich, K. (2011). Analyzing Corporate Social Responsibility's Impact on Employee Attraction and Retention with a Focus on Generation Y. Fielding Graduate University.

Peterson, D.K. (2004). The relationship between perceptions between corporate citizenship and organisational commitment. Business and Society, 43, 296-319.

Pienaar, M. (2010). Factors Affecting the Attraction and Retention of Generation Y at a Petroleum Company-What Role does Corporate Social Responsibility Play?. University of Cape Town, Available from: http://gsblibrary.uct.ac.za/researchreports/2010/Pienaar.pdf.

PricewaterhouseCoopers $(\mathrm{PwC})$ (2011). Millennials at Work: Reshaping the Workplace.Pricewater houseCoopers International (PwCIL), Available from: https:/www.pwc.com/m1/en/services/ consulting/documents/millennials-at-work.pdf.

Pyszka, A., \& Gajda, D. (2015). Successful talent management through positive csr-driven transactions. Journal of Positive Management, 6(2), 3.

Queiri, A., Wan Yusoff, W.F., \& Dwaikat, N. (2014). Generation-Y employees' turnover: Work-values fit perspective. International Journal of Business and Management, 9(11), 199-213, doi: 10.5539/ ijbm.v9n11p199.

Queiri, A., Wan Yusoff, W.F., \& Dwaikat, N. (2015). Explaining generation-Y employees' turnover in Malaysian context. Asian Social Science, 11(10), 126-138, doi: 10.5539/ass.v11n10p126.

Rudominer, R. (2016). Corporate Social Responsibility Matters: Ignore Millennials at Your Peril. Center for Social Impact Coomunication, School of Continuing Studies, Georgetown University, Available from: https://csic.georgetown.edu/magazine/corporate-social-responsibility-mattersignore-millennials-peril/.

Rupp, D.E., Aguilera, R.V., Ganapathi, J., \& Williams, C. (2013). Employee reactions to corporate social responsibility: An organisational justice framework. Journal of Organisational Behavior, 27(4), $537-543$.

Sabrina, D. (2017). Rising Trend: Social Responsibility is High on Millennials' list, Available from: https://www.huffpost.com/entry/rising-trend-social-respo_b_14578380.

Sammut, M. (2014). Corporate social responsibility: 3 ways to connect with gen Y. 360 Campus Recruitmen, Available from: https//360.talentegg.ca/2014/07/corporate-social-responsibility-3ways-to-connect-with-gen-y/.

Schmidt, L. (2016). Why retention will Be the biggest talent challenge of 2017. Forbes, (August 2007), 2, Available from: https://www.forbes.com.

Schwartz, M.S., \& Carroll, A.B. (2003). Corporate social responsibility: A three-domain approach. Business Ethics Quarterly, 13(4), 503-530.

Sekaran, U. (2013). Research Methods for Business (4th ed.) 65. New York, NY: John Wiley \& Sons, doi: 10.1017/CBO9781107415324.004.

Shahvazian, S., Mortazav, S., Lagzian, M., \& Rahimnia, F. (2016). A dichotomous perceptions on talent retention factors: Phenomenography strategy. Iranian Journal of Management Studies (IJMS), 9(4), 675-706.

Shanmugam, K. (2013). Environment CSR initiatives of manufacturing units in India-an empirical study. African Journal of Business Management, 7(16), 1560-1570. 
Smola, K.W., \& Sutton, C.D. (2002). Generational differences: Revisiting generational work values for the new millennium. Journal of Organisational Behaviour, 23(1), 363-82, doi: 10.1002/ job.147.

Stephenson, A. (2009). The pursuit of CSR and business ethics policies: Is it a source of competitive advantage for organizations? The Journal of American Academy of Business, 14(2), 251-262.

Sujana, A. (2014). Corporate social responsibility activities in Australian small and medium sized accountancy firms. International Journal of Management Research and Business Strategy, 3(1), 159-168.

Tajuddin, D., Ali, R., \& Kamaruddin, B.H. (2015). Developing talent management crisis model for quality life of bank employees in Malaysia. Procedia - Social and Behavioral Sciences, 201(February), 80-84, doi: 10.1016/j.sbspro.2015.08.133.

Talent Corporation Malaysia Berhad (TalentCorp) (2016). Malaysia's Critical Occupations List 2015/ 2016, Available from: https://www.talentcorp.com.my.

Tatoglu, E., Glaister, A.J., \& Demirbag, M. (2016). Talent management motives and practices in an emerging market: A comparison between MNEs and local firms. Journal of World Business, 51(2), 278-293, doi: 10.1016/j.jwb.2015.11.001.

Tilt, C.A. (2009). Chapter 1 corporate responsibility, accounting and accountants. In S.O. Idowu \& W.L. Filho (Eds), Professionals' Perspectives of Corporate Social Responsibility, Springer-Verlag, Berlin, Heilderberg, doi: 10.1007/978-3-642-02630-0.

Toliver, A.D. (2013). Measuring Corporate Social Responsibility Through Organizational Values: A Scale Validation Study. PhD Thesis, The University of Texas at Arlington, Available from: https://rc.library.uta.edu/uta-ir/bitstream/handle/10106/25553/Toliver_uta_2502D_12286.pdf? sequence $=1$.

Turker, D. (2009). Measuring corporate social responsibility: A scale development study. Journal of Business Ethics, 85(4), 411-427.

Van Leeuwen, D. (2010). Gen Y Rewards Companies that Take Corporate Social Responsibility Seriously, Available from: http://www.tomorrowtodayglobal.com/2010/11/13/gen-y-rewardscompanies-that-take-corporate-social-responsibility-seriously/.

Wallop, H. (2014). Gen Z, Gen Y, Baby Boomers - a Guide to the Generations. Telegraph, 1-7, Available from: http://www.telegraph.co.uk/news/features/11002767/Gen-Z-Gen-Y-baby-boomers-a-guideto-the-generations.htm.

Wee, T.C. (2013). Talent retention: The pressures in Malaysia smes. American Journal of Economics, 3, 35-40, doi: 10.5923/c.economics.201301.07.

Weerasinghe, G. (2017). Impact of talent management on employee retention: A study carried out on travel agency in Sri Lanka. International Journal of Multidisciplinary Research and Development 4(4), 54-58.

Wong, K.A., Wan, Y.K.P., \& Gao, J.H. (2017). How to attract and retain generation Y employees? An exploration of career choice and the meaning of work. Tourism Management Perspectives, 23, $140-150$.

Yin, K.S. (2015). Employee retention remains a key challenge in Malaysia claim supervisors face challenges in making time to perform their most important task. Towers Watson, Available from: https://www.towerswatson.com/en/Press/2015/01/Employee-Retention-Remains-A-KeyChallenge-in-Malaysia.

Zheng, C., Soosay, C., \& Hyland, P. (2007). Manufacturing to Asia: Who will win the emerging battle for talent between dragons and Tigers? Journal of Manufacturing Technology Management, 19(1), 52-72.

Zunker, V.G. (1994). Career counseling: Applied concepts of life planning. California: Brooks/Cole Publishing. 
REGE

27,4

392

\section{Further reading}

Malaysian Institute of Accountants (MIA). (2016a). MIA annual report 2016, Available from: http:// www.mia.org.my.

Malaysian Institute of Accountants (MIA). (2016b). Public practice, Available from: http://www.mia. org.my.

Tlaiss, H.A., Martin, P., Hofaidhllaoui, M. (2017). Talent retention: Evidence from a multinational firm in France. Employee Relations, 39(4), 426-445, doi: 10.1108/ER-07-2016-0130.

\section{Corresponding author}

Fadilah Puteh can be contacted at: fadilahputeh55@gmail.com

Associate Editor: Angela Lucas

For instructions on how to order reprints of this article, please visit our website: www.emeraldgrouppublishing.com/licensing/reprints.htm Or contact us for further details: permissions@emeraldinsight.com 